\title{
Long onlay bypass grafting using the left internal mammary artery for proximal and mid stenosis of the left anterior descending artery
}

\author{
Bilgin Emrecan ${ }^{1}$, Ahmet Coşkun Özdemir ${ }^{2}$, Yusuf İzzettin Alihanoğlu³, İsmail Doğu Kılıç3 \\ ${ }^{1}$ Department of Cardiac and Vascular Surgery, Pamukkale University, Denizli, Turkey \\ ${ }^{2}$ Department of Cardiac and Vascular Surgery, Denizli Cerrahi Hospital, Denizli, Turkey \\ ${ }^{3}$ Department of Cardiology, Pamukkale University, Denizli, Turkey
}

Kardiochirurgia i Torakochirurgia Polska 2013; 10 (4): 325-329

\begin{abstract}
Aim of the study: According to the literature, many surgeons aim to obtain complete revascularization during coronary artery surgery. This becomes an issue when the left anterior descending (LAD) artery is diffusely diseased. This study presents the results of revascularization surgery of LAD arteries with multiple stenoses and the subsequent angiographic control examinations.

Material and methods: Forty-seven patients with proximal and mid-segment left anterior descending (LAD) artery disease were included in the study. Left anterior descending arteries were bypassed with left internal mammary arteries (LIMAs). Left anterior descending arteries were longitudinally opened over the mid stenotic segments $4-5 \mathrm{~mm}$ distally and proximally from the stenosis. The LIMAs were then anastomosed to the LAD arteries with a running suture, using 7-0 polypropylene sutures.

Thirteen patients, who provided their informed consent, were angiographically evaluated at a mean of $12.5 \pm 3.7$ months after the operation (range 6-18 months).

Results: The mean age of the patients was $64.1 \pm 8.9$ years. The mean number of distal anastomoses was $3.5 \pm 0.9$ (range 1-6). The mean length of LAD anastomoses was $1.88 \pm 0.54 \mathrm{~cm}$ (range 1.5-4 cm). Cardiac troponin I levels were below perioperative myocardial infarction thresholds.

Mean postoperative hospitalization was $6.10 \pm 0.98$ days (range 5-9 days). There was no mortality in the study group. Control angiography revealed patent bypass grafts in all patients.

Conclusions: Long anastomosis to the LAD artery provides excellent mid-term patency. It is safe and effective in perfusing the proximal and distal non-stenotic segments of the LAD artery, as well as in perfusing the unoccluded side branches originating from the stenotic segments.

Key words: coronary artery disease, bypass, surgery.
\end{abstract}

\section{Streszczenie}

Cel pracy: Jak wskazują dane dostępne w piśmiennictwie, wielu chirurgów stara się osiągnąć całkowitą rewaskularyzację przy operacjach tętnicy wieńcowej. Może to stanowić problem, gdy tętnica lewa przednia zstępująca (ang. left anterior descending - LAD) jest objęta rozproszonym procesem chorobowym. W niniejszej pracy przedstawiono wyniki rewaskularyzacji i badań angiograficznych przeprowadzonych u pacjentów z licznymi zwężeniami w obrębie LAD.

Materiał i metody: Badaniem objęto 47 pacjentów cierpiących z powodu choroby proksymalnego i środkowego odcinka tętnicy LAD. Wykonano pomostowanie tętnic LAD za pomocą tętnic piersiowych wewnętrznych (left internal mammary arteries - LIMA). Tętnice LAD zostały otwarte wzdłużnie w obszarze zwężenia środkowego; nacięcie sięgało 4-5 mm poza granice zwężenia po każdej jego stronie. Tętnice LIMA zostały następnie zespolone z tętnicami LAD za pomocą szwu ciągłego, przy użyciu nici polipropylenowych 7-0.

Trzynaścioro pacjentów, po wyrażeniu świadomej zgody, zostato poddanych badaniom angiograficznym po średnio $12,5 \pm 3,7$ miesiąca po operacji (zakres 6-18 miesięcy).

Wyniki: Średni wiek pacjentów wynosił $64,1 \pm 8,9$ roku. Średnia liczba zespoleń dystalnych wynosiła 3,5 $\pm 0,9$ (zakres 1-6). Średnia długość zespoleń LAD wynosiła 1,88 $\pm 0,54 \mathrm{~cm}$ (zakres 1,5-4 cm). Wartości stężenia sercowej troponiny I znajdowały się poniżej poziomu zawału okołooperacyjnego.

Średni okres hospitalizacji pooperacyjnej wynosił 6,10 $\pm 0,98$ dnia (zakres 5-9 dni). W badanej grupie nie było zgonów. Kontrolne badania angiograficzne wykazały drożność pomostów u wszystkich pacjentów.

Wnioski: Długie pomostowanie tętnicy LAD zapewnia doskonałą drożność średniookresową. Jest to bezpieczna i efektywna metoda perfuzji proksymalnych i dystalnych niezwężonych odcinków tętnicy LAD, jak również niezablokowanych gałęzi bocznych odchodzących od odcinków objętych stenozą.

Słowa kluczowe: choroba tętnic wieńcowych, pomostowanie, chirurgia.

Address for correspondence: Assoc. Prof. Bilgin Emrecan, Medical Faculty, Pamukkale University, Yunus Emre Cad no 83/5 kınıkl, 20070 Denizli, Turkey, tel. +90 50548899 16, e-mail: bilginemrecan@yahoo.com 


\section{Introduction}

Complete revascularization of the left anterior descending (LAD) artery is the main goal of coronary artery bypass grafting due to the fact that incomplete revascularization results in higher mortality. Ischemia of the myocardium supplied by the side branches can be relieved by combined endarterectomy and coronary artery reconstruction in a diffusely diseased $L A D$, which cannot be achieved only by performing anastomosis to the distal undiseased segment of the artery [1].

Nearly five percent of coronary arteries are not suitable for surgery because of extensive atheromatous lesions along the coronary vessel. Besides long reconstruction, the literature also describes the use of long open endarterectomy for this type of lesion [2]. Regardless of the revascularization method of choice, it is obvious that these lesions are challenging for surgeons and interventional cardiologists.
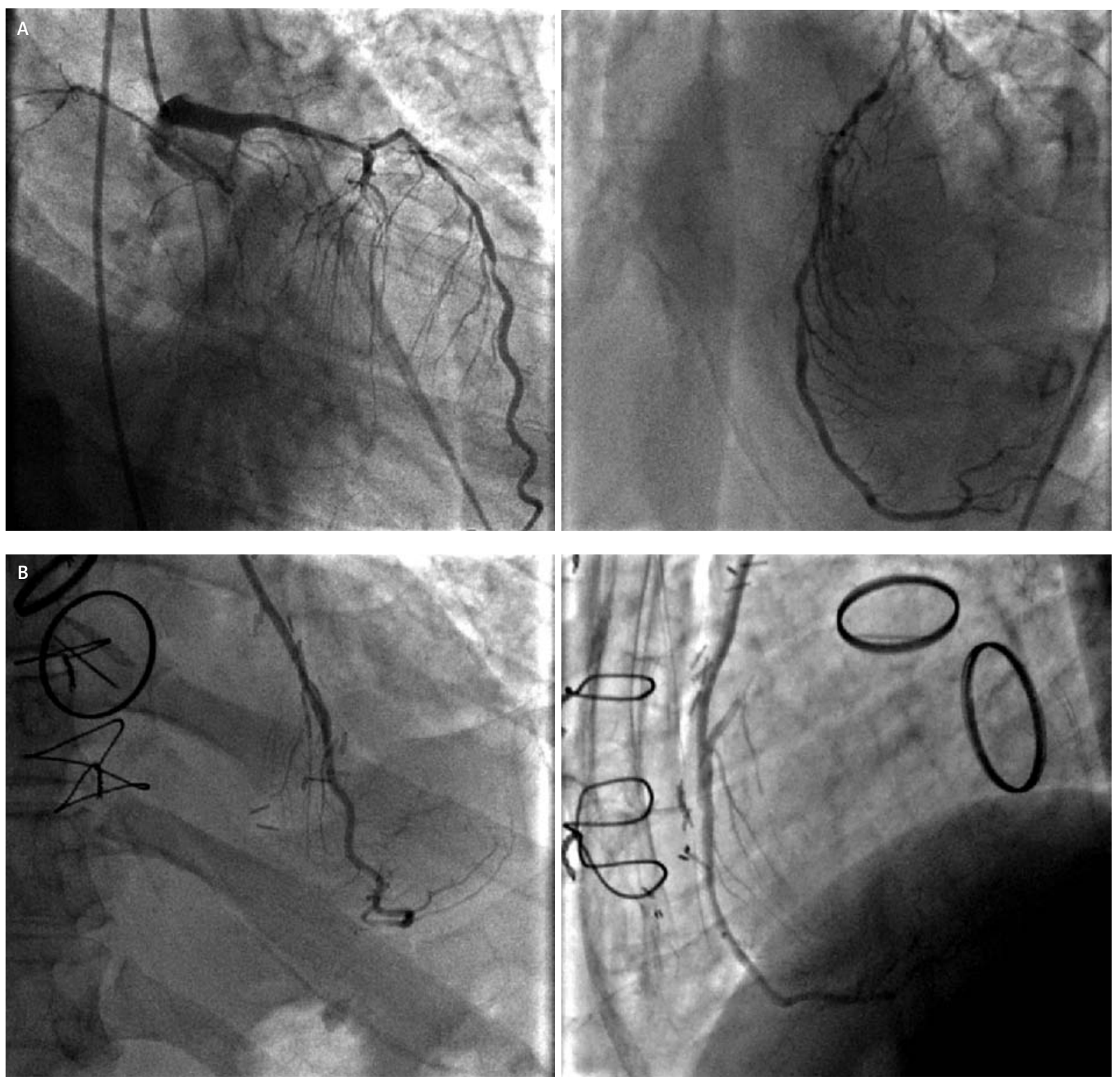

Fig. 1A-B. A) Preoperative coronary angiography showing the proximal and mid stenosis of the LAD artery, B) postoperative coronary angiography showing the LIMA-to-LAD anastomosis
In the present study, we retrospectively evaluated the early postoperative outcomes of patients with coronary bypass surgery whose LAD arteries were diffusely stenotic. The LAD arteries were bypassed with a long anastomosis excluding the stenotic mid-segment. The patients who provided their consent underwent control angiographic evaluation.

\section{Material and methods}

\section{Patients}

Between June 2010 and December 2012, a total of 47 patients with stable or unstable angina pectoris and a diagnosis of coronary artery disease underwent coronary artery bycollected. Patients with proximal and mid-segment stenosis of the LAD artery concomitant with other vascular diseases were included in the study (Fig. 1). All LAD arteries had pass surgery. The data of the patients were retrospectively 
coexisting proximal and mid-segment stenoses, which were bypassed using left internal mammary arteries (LIMAs).

\section{Surgical technique}

The chests of the patients were opened by means of median sternotomy, under general anesthesia and intratracheal intubation. The LIMAs were harvested before pericardiotomy. Anticoagulation was accomplished with $4 \mathrm{mg} / \mathrm{kg}$ body weight of heparin until the target activated clotting time of 450 seconds was achieved. Standard cardiopulmonary bypass techniques were used for the operations. Antegrade isothermic hyperkalemic blood cardioplegia was used for myocardial protection. LIMA-LAD coronary artery bypass grafting was performed after conducting distal anastomoses of other vessels. Saphenous vein grafts were used for the revascularization of these vessels. Long LAD arteriotomy was performed on the stenotic mid-segment of the LAD artery (Fig. 2). Mid-segment lesions were opened starting distally 3-4 mm away from the stenosis. The arteriotomies were performed proximally, and the stenotic lesions were opened longitudinally. The arteriotomies extended to the proximal undiseased segment of LAD, 3-4 mm proximally to the stenosis. The LIMAs were then anastomosed to the LAD arteries with a running suture technique, using 7-0 polypropylene sutures (Fig. 3). After declamping, proximal anastomosis was performed on the aorta. After the cardiopulmonary bypass was completed, heparin was neutralized by protamine sulfate, while the chest was closed in a standard fashion.

Cardiac troponin I was measured before the surgery and 24 hours after. The preoperative and postoperative data of the patients were analyzed. Demographic and operation data were collected and analyzed using the SPSS statistical software version 17.0 (SPSS Inc.; Chicago, III). Continuous variables were expressed as mean \pm SD and were compared by means of the paired samples $t$-test; $p$ values below 0.05 were considered statistically significant.

In total, 47 patients were called in for outpatient control. Thirteen patients who requested control examination

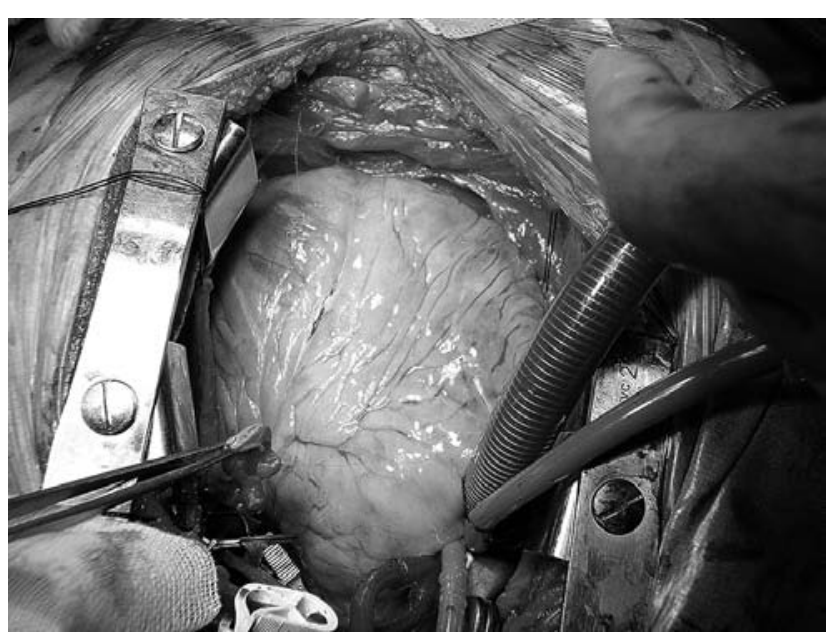

Fig. 2. Long $L A D$ arteriotomy performed across the stenotic midsegment of the LAD artery underwent coronary angiographic evaluation at a mean of $12.5 \pm 3.7$ months after surgery (range 6-18 months). All of these patients provided their written informed consent.

\section{Results}

The study included 13 female and 34 male patients. The mean age of the patients was $64.1 \pm 8.9$ years. The risk factors were diabetes (16 patients), hypertension (13 patients), hypercholesterolemia (19 patients), smoking (9 patients), peripheral arterial occlusive disease ( 5 patients), and family history of coronary artery disease (8 patients). Eight of the patients suffered from comorbid chronic obstructive pulmonary disease.

Mean left ventricular ejection fraction was $52 \pm 9 \%$ (range $30-70 \%)$, The mean number of distal anastomoses was 3.5 \pm 0.9 (range 1-6). The mean length of LAD anastomoses was $1.88 \pm 0.54 \mathrm{~cm}$ (range $1.5-4 \mathrm{~cm}$ ). Although the postoperative levels of cardiac troponin I were significantly higher than the preoperative levels (preoperative: $0.070 \pm 0.120 \mathrm{IU}$, postoperative: $0.442 \pm 0.375 \mathrm{IU}, p<0.001$ ), they remained below perioperative myocardial infarction thresholds.

Mean intensive care unit follow-up stay was $1.13 \pm 0.34$ days (range 1-2 days), while mean postoperative hospitalization lasted for $6.10 \pm 0.98$ days (range 5-9 days). The discharged patients were prescribed oral antiaggregant agents. There was no mortality in the study group.

The data concerning the 13 patients who underwent control angiography are as follows: mean number of distal anastomoses - $3.5 \pm 1.0$ (range 2-6), mean length of LAD artery anastomosis $-1.92 \pm 0.57 \mathrm{~cm}$ (range $1.5-3 \mathrm{~cm}$ ). All LIMAs were patent (Fig. 3). One patient suffered from proximal saphenous vein stenosis of $50 \%$.

\section{Discussion}

In the present study, long anastomosis to the LAD artery showed excellent mid-term patency. The limited number of patients was the major limitation of the study. Simple arteriotomy, beginning from the distal side of the long stenotic segment

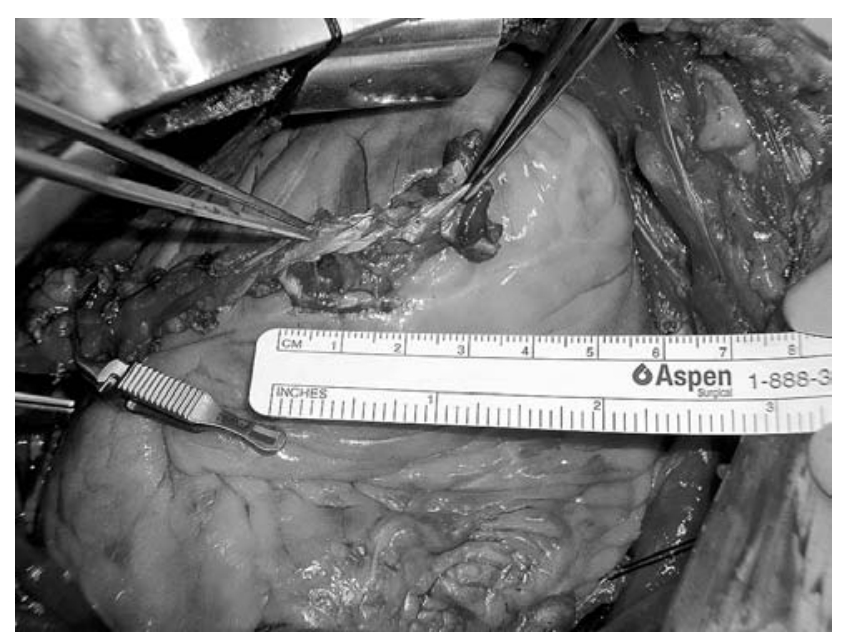

Fig. 3. The LIMA anastomosed to the LAD artery with a running suture 
of the LAD artery, made the anastomosis straightforward and uneventful in all of the patients. In contrast to the available literature, no endarterectomy was necessary in these patients.

Long arteriotomy extending over a heavily plaqued area has been proposed in diffuse LAD artery disease [3]. Extended reconstruction of the LAD coronary artery with a saphenous vein graft, as well as internal mammary artery grafting, has been found to increase surgical risk. However, this technique is suggested due to the complete revascularization and acceptable mid-term results it provides [4]. Some surgeons exclude the atheromatous plaques from the LAD artery lumen and leave them outside the anastomosis. They suture an ITA patch inside the LAD artery in order to exclude the plaques from its lumen. However, this technique was only successful in $84 \%$ of cases; endarterectomy was required in the remaining cases. This technique has been proven to stop the growth of the plaques excluded from the lumen of the LAD artery; postoperative intimal fibroplasia has been found to decrease as well [2].

Another disadvantage of endarterectomy is that it triggers a coagulation cascade in the early postoperative period [5]. In our series, we did not touch the atheromatous plaques. The stenotic segments were longitudinally opened, and the LIMAs were anastomosed to the opened LAD arteries. This means that intimal fibroplasia was not the primary problem in our series, owing to the fact that we did not endarterectomize the LAD arteries; occluded side branches may not be perfused due to their being occluded by the plaque. The goal of the anastomosis in our series was to perfuse the proximal and distal LAD artery segments. One technical challenge that we encountered was that it was sometimes difficult to pass a needle through the diseased artery. Nevertheless, there were no patients whose LAD arteries could not be anastomosed.

In a study by Fukui et al. the patency rate of extensive reconstruction without endarterectomy was found to be better than in the case of reconstruction with endarterectomy. The authors concluded that residual lesions of the LAD or circumflex arteries constitute predictive factors for coronary artery bypass graft (CABG) survival. A secure anastomosis without obstruction of the side branches originating from the anastomosis site may be done by exposing their ostia. The authors suggest opening the lesion in order to provide sufficient blood supply to these side branches [5]. In our series, we could also easily leave these side branches outside the suture line of the anastomosis.

Long segmental anastomosis with or without endarterectomy has been safely and effectively performed using the off-pump method. LAD arteries affected by severe diffuse disease are reported to withstand longer periods of ischemia during anastomosis because of well-developed significant collaterals [5]. Another study, on the other hand, found similar long-term graft patency on endarterectomized and non-endarterectomized LADs [6]. However, such a long anastomosis in such a long open stenotic segment may complicate the anastomosis when the heart is beating. Therefore, we do not prefer off-pump surgery when considering long onlay patch anastomosis. In accordance with our current technique, which is in line with the methods used by other authors, we avoid touching the most proximal major stenotic lesion to prevent competitive flow and preserve all coronary branches, such as the septal and diagonal branches [7].

In the case of calcified plaques, placing sutures around them to exclude them from the neo-coronary vessel lumen has the advantage of preserving the endothelium. Thrombogenicity and neointimal proliferation are thus minimized. Oral anticoagulation is, to some extent, avoided in the immediate postoperative period [8]. We do not endarterectomize the plaques. Instead we discharge the patients after providing them with oral antithrombotic agents.

Some authors suggest the use of sequential grafting in multisegment stenotic LAD arteries [9]. However, sequential grafting has its disadvantages: proximal anastomosis may cause kinking of LIMA grafts and proximal anastomotic stenosis may occur on LIMAs when wide suture bites are taken. Furthermore, when proximal runoff is higher, the distal LIMA may become occluded. This is true for all sequential grafts. Distal anastomosis should be performed on the artery with the highest runoff.

This article is a retrospective observational study, and it does not contain any comparison with conventional CABG in patients with diffusely diseased LADs. There was no control group and the study population was small. It was not possible to analyze all the anastomoses angiographically, but unnecessary control angiography may result in certain undesired complications. The follow-up period was short, which made it difficult to draw any binding conclusions.

To conclude, long anastomosis used to reconstruct a diffusely stenotic LAD artery with a LIMA graft is safe and effective in perfusing the proximal and distal nonstenotic segments of the LAD artery, as well as in perfusing the unoccluded side branches originating from the stenotic segments. It presents excellent early and short-term results. Endarterectomy should be avoided when possible.

\section{References}

1. Fukui T, Takanashi S, Hosoda Y. Long segmental reconstruction of diffusely diseased left anterior descending coronary artery with left internal thoracic artery with or without endarterectomy. Ann Thorac Surg 2005; 80: 2098-2105.

2. Barra JA, Bezon E, Mondine P, Resk A, Gilard M, Mansourati J, Boshat J. Surgical angioplasty with exclusion of atheromatous plaques in case of diffuse disease of the left anterior descending artery: 2 years' follow-up. Eur J Cardiothorac Surg 2000; 17: 509-514.

3. Doss M, Martens S, Wood P, Tsoukalas I, Moritz A. Five-year follow-up after long plaque-bridging coronary arteriotomy for diffuse coronary artery disease. Thorac Cardiovasc Surg 2003, 51: 318-321.

4. Santini F, Casali G, Lusini M, D’Onofrio A, Barbieri E, Rigatelli G, Franco G, Mazzucco A. Mid-term results after extensive vein patch reconstruction and internal mammary grafting of the diffusely diseased left anterior descending coronary artery. Eur J Cardiothorac Surg 2002; 21: 1020-1025.

5. Fukui T, Tabata M, Taguri M, Manabe S, Morita S, Takanashi S. Extensive reconstruction of the left anterior descending coronary artery with an internal thoracic artery graft. Ann Thorac Surg 2011; 91: 445-451.

6. Okur FF, Uyar IS, Evrengül H, Sahin V, Akpinar B, Abacilar F, Yurtman V, Ateş $M$. Results of coronary artery bypass grafting with coronary endarterectomy. Turk Gogus Kalp Dama 2012; 20: 1-7. 
7. Takanashi S, Fukui T, Hosoda Y, Shimizu Y. Off-pump long onlay bypass grafting using left internal mammary artery for diffusely diseased coronary artery. Ann Thorac Surg 2003; 76: 635-637.

8. Prabhu AD, Thazhkuni IE, Rajendran S, Thamaran RA, Vellachamy KA, Vettath MP. Mammary artery patch reconstruction of left anterior descending coronary artery. Asian Cardiovasc Thorac Ann 2008; 16: 313-317.

9. Mert M, Cetin G, Yildiz CE, Ugurlucan M, Caglar IM, Ozkara A, Akcevin A, Bakay C. Long term follow up results of sequential left internal thoracic artery grafts on severe left anterior descending artery disease. J Cardiothorac Surg 2010; 5: 87. 